\title{
Social and Economic Effects of the Menace of Fulani Herdsmen Crises in Nigeria
}

\author{
Ajibefun, M. B. \\ School of Management Technology, \\ Federal University of Technology, \\ Akure, Ondo State
}

Doi: 10.2478/jesr-2018-0024

\begin{abstract}
This study investigated the social and economic effects of the menace of Fulani herdsmen crises in Nigeria. The study specifically examined the causes of Fulani herdsmen and farmers clashes in Nigeria, and the social and economic effects of the menace of Fulani herdsmen in Nigeria. The sample of the study consisted of 250 farmers and 150 respondents from Fulani tribe selected from affected Local Government areas in Southwest, Nigeria via purposive sampling technique. A questionnaire titled Economic and Social Effects of Herdsmen Clashes Questionnaire (ESEHCQ) was used to collect data. Descriptive statistics and inferential statistics of t-test were used to analyze the data generated from respondents. The findings revealed that the major cause of the conflict was destruction of crops. The social effect of the menace of Fulani herdsmen are loss of human life, sexual harassment of human life, acquiring of weapons/arms, reduction in quality of social relationship, reduction of social support and high cases of rape while the economic effect of the menace of Fulani herdsmen are reduction in output and income of farmers/nomads, loss of produce in storage, displacement of farmers, scarcity of agricultural products, loss of house and properties and infrastructural damages. The findings also revealed that farmers and Fulani perception of the causes of Fulani herdsmen and farmers clashes in Nigeria are not different while farmers and Fulani perception of the social effects and economic effects of Fulani herdsmen and farmers clashes in Nigeria are different. Based on the findings, it was recommended among others that representatives of the host communities and Fulani herdsmen should be conveyed under a public forum and involved in the decision making and permitted to take part actively in the planning procedure of restoring peace to most of the affected communities.
\end{abstract}

Keywords: Social Effect, Economic Effect, Fulani, Herdsmen, Crises

\section{Introduction}

The Fula origin also known as Fulani are a mass inhabitants widely dispersed in all of Africa, but most predominant in West Africa. The Fulani people are descendants from Middle East and North Africa. However, the history of the Fulani origin began with the Berbers of North Africa around the 8th or 11th century AD (Anter, 2015). Over a millennium ago from AD 900 - 1900, they spread to most parts of West Africa and to some areas of Central Africa (Anter, 2015). The Fulani migrants were predominantly Muslims. As the population increases, the number of converts to Islam also increased. In the opening of 18th century, there were revolts between the Fulani and the local people. Although, these uprisings began as holy wars (jihads), after their triumph they followed the basic standard of Fulani ethnic dominance in most West African States.

Most of the Fulani people are nomadic in nature, herding sheep, goats and cattle across the dry grass lands of their environs and making them the main pastoral nomadic group in the world. The main Fulani sub groups in Nigeria are: Fulbe Gombe, Fulbe Adamawa, Fulbe Sokoto, Fulbe 
Mbororo, and Fulbe Borgu (Kasarachi, 2016). The Fulani unarguably represent a significant part of the economy of Nigeria. They are the major breeders of goats, sheep and cattle as those animals are the major source of meat and affordable source of animal proteins ate by Nigerians.

The Fulani own over ninety percent of the livestock population which accounts for one-third of agricultural GDP and 3.2\% of the entire GDP in Nigeria (Fabiyi \& Otunuga, 2016). The Fulani herdsmen mostly move with their cattle's from one destination to another in search of grazing land especially in the dry season. When the Fulani light-skinned herders are migrating, they are often accompanied by their dark-skinned sedentary kinsmen (urban or town Fulani), who are better educated, more dynamic as politicians, and were fanatical and versed as Muslims than the former. When the herders encounter local opposition to their encroachments, the sedentaries provide the requisite political and military strategy for resistance, and when the sedentaries felt the need for socio-religious cleansing (a jihad), the herdsmen provide the rank and file of the fighting forces.

However, the Fulani herders in most cases settled in fertile areas to rear their cattle and when the migration continued to be dictated by economic and socio-political factors, increased trends of conflicts between the herders and their host communities (farmers) escalated. Many Nigerians lost their lives, properties/ farmlands or crops every year to Fulani herders. The conflicts between Fulani herdsmen and farmers came into existence as a result of encroachment of farmlands by the Fulani herders.

Nigeria is under a severe internal and security threat as the threat has political, economic and environmental dimensions. Each of these dimensions has critically affected the stability of the nation and can be traced to many factors in which the Fulani-herdsmen appears to be major factor. Most worrisome in the present development is the pillaging, raping, killing and kidnapping by the so called Fulani herdsmen. Stories are found in the national dailies on daily basis of how these shepherds strategically attack several communities and houses, with sophisticated assault gunsAK-47.

According to Okereke (2012) and Bello (2013), the conflicts in most part of Nigeria especially the Fulani herdsmen and farmers clash are largely uncalled for. Farmers can no longer farm peacefully because of Fulani herdsmen. These Fulani herdsmen and farmers clash have pitched Christians and Muslims against each other. Recent studies conducted by Okereke (2012) and Kasarachi (2016) have shown that, serious conflict erupt between Fulani herdsmen and farmers leading to loss of lives, valuable properties and destruction of vast expanse of arable agricultural farmlands thereby posing serious threat to food security since farmers for fear of attack could no longer go to farm and harvest their farm produce. The latest attacks by Fulani herdsmen is on the upsurge, with the most latest attacks in February 2018 happening in Benue State, Taraba State, Nassarawa State and few cases of attack in other states.

In recent times, the killings recorded by Fulani herdsmen and farmers clash has rampaged most communities displacing them of their farmlands and loss of their major source of livelihood. This is becoming unbearable with the Fulani herdsmen always having their ways leaving the farmers at their mercy. Herdsmen attribute the roots of the crisis to religious differences resulting in the killing of their cows while the farmers see the herdsmen as a threat to their crops and agricultural produce since the herdsmen allow their cows to feed on the farmer crops.

This recent wave of violence in Nigeria as observed by Kasarachi (2016) has disrupted socioeconomic, religious and educational activities, political instability and threatened the national unity in Nigeria. These extra judiciary killings have forced thousands of people to abandon their homes and farmlands for safety. Okereke (2012) asserts that this unfolding violence have become so alarming that there is no gainsaying the fact that Nigeria is at a crossroad and gradually drifting to a conflict society. Equally begging for answers are the social issues of the rape of women, robbery and kidnapping with ultimate intent for ransom.

The researcher observed that the menace of Fulani-Herdsmen appears to have dire implications for socio-economic development in the states attacked and Nigeria in general. In the states where the Fulani herdsmen and farmers crisis is pervasive, the property destroyed and cases of rapes slog their economic and social opulence back by several steps. Besides the destroyed properties, socio-economic life in those states is usually grounded to a halt as people could not freely go about their farming and socio-economic activities for fear of being killed. 
The overall implication for sustainable development is that the farming, economic and social activities seem to be fast deteriorating. Also, a substantial part of the country's budget has been spent on the compensation of families who lost their relations to the Fulani herdsmen and farmers crisis. Also, huge amount of money is being spent on weapons and ammunition acquisition so as to equip the military to handle the situation on ground. All these seem to have affected Nigeria's economy.

These observations have attracted the attention of this researcher to investigate the social and economic effects of the menace of Fulani herdsmen in Nigeria.

Nigeria is seriously threatened by Fulani herdsmen and farmers crisis and therefore, considered to be a main threat affecting the social and economic activities of the nation. Fulani herdsmen and farmers clashes seem to have become a major problem to the security and development of Nigeria

The frequent occurrence of Fulani herdsmen and farmers crisis appears to have left adverse effects on socio-economic development of the people. Fulani herdsmen and farmers crisis no doubt have negative impact on social and economic development in Nigeria. Though, there is the dearth of quantitative evaluation of the effect and negative impact of Fulani herdsmen and farmers crisis in Nigeria. The problem of this study is there to investigate the social and economic effects of the menace of Fulani - Herdsmen crises in Nigeria.

The study was carried out with three objectives of finding out:

1. The causes of Fulani - Herdsmen and farmers clashes in Nigeria;

2. The social effects of the menace of Fulani - Herdsmen in Nigeria; and

3. The economic effects of the menace of Fulani - Herdsmen in Nigeria.

Based on the above, the following hypotheses are postulated for this study.

1. There is no significant difference between farmers and Fulani perception of the causes of Fulani - Herdsmen and farmers clashes in Nigeria.

2. There is no significant difference between farmers and Fulani perception of the social effects of Fulani - Herdsmen and farmers clashes in Nigeria.

3. There is no significant difference between farmers and Fulani perception of the social effects of Fulani - Herdsmen and farmers clashes in Nigeria.

\section{Research Methodology}

A descriptive survey design was adopted which enabled the researchers to collect and analyze data from a sample of the entire population without any manipulations. The population for the study were all farmers and Fulani tribe residents in Southwest, Nigeria. The sample consisted of 250 farmers and 150 respondents from Fulani tribe selected from affected Local Government areas in Southwest, Nigeria via purposive sampling technique.

A well-constructed and self-developed questionnaire titled "Economic and Social Effects of Herdsmen Clashes Questionnaire (ESEHCQ)" was used to gather the information needed in this study. ESEHCQ was divided into three sections namely section A, B and C. Section A sought for the personal data of respondents, Section B consisted of items that elicited responses on the causes of Fulani - Herdsmen and farmers clashes from the respondents while section $\mathrm{C}$ elicited information on social and economic Effect of Fulani - Herdsmen and farmers clashes from the respondents. Likert 4 - point rating scale was adopted to rate response options which are Strongly Agree (SA), Agree (A), Disagree (D) and Strongly Disagree (SD).

The face and content validity was ascertained by giving the designed questionnaire to experts of Tests and Measurement for vetting before distributing it to the respondents. The data generated through the instrument were analyzed using the descriptive statistics of frequency counts and percentage, mean, standard deviation while the hypotheses were tested using inferential statistics of t-test analysis. All hypotheses were tested at 0.05 level of significance. 


\section{Results}

\subsection{Question 1: What are the causes of Fulani Herdsmen and farmers clashes in Nigeria?}

The average mean scores cause of Fulani Herdsmen was computed as presented in table 1 , bearing in mind that the mean cut off in 2.50

Table 1: Causes of Fulani - Herdsmen and farmers clashes in Nigeria

\begin{tabular}{|c|l|c|c|c|c|}
\hline S/N & Causes & \multicolumn{2}{c|}{ Farmers } & \multicolumn{2}{c|}{ Fulani-Herdsmen } \\
\hline & & Mean & Remark & Mean & Remark \\
\hline 1. & Destruction of crops & 4.0 & Accepted & 3.2 & Accepted \\
\hline 2. & Over- grazing of fallow land & 2.4 & Rejected & 2.1 & Rejected \\
\hline 3. & Harassment of nomads by host youths & 2.7 & Accepted & 3.0 & Accepted \\
\hline 4. & Contamination of stream by cattle & 2.3 & Rejected & 2.1 & Rejected \\
\hline 5. & Theft of cattle & 2.0 & Rejected & 3.0 & Accepted \\
\hline 6. & Disregard for traditional authority & 2.6 & Accepted & 2.1 & Rejected \\
\hline 7. & Stray cattle & 2.6 & Accepted & 2.3 & Rejected \\
\hline 8. & Sexual harassment of women by nomads & 2.9 & Accepted & 3.1 & Accepted \\
\hline 9. & Indiscriminate bush burning & 2.8 & Accepted & 2.6 & Accepted \\
\hline 10. & Indiscriminate defecation by cattle on roads & 2.1 & Rejected & 2.2 & Rejected \\
\hline
\end{tabular}

Mean Cut-off: 2.50

Table 1 reveals that the major cause of Fulani - Herdsmen and farmers clashes was destruction of crops (mean $=4.0$ ). However, the Fulani herdsmen opinion of this as a cause of conflict was not as high as farmers' opinion (mean $=3.2$ ). Another major cause as rated by farmers was the sexual harassment of women by nomads (mean $=2.9$ ). The herdsmen also regarded sexual harassment as a cause of conflict (mean $=3.1$ ).

Another major cause of conflict as opined by the farmers (mean $=2.8$ ) was indiscriminate bush burning. The Fulani-Herdsmen also regarded the indiscriminate bush burning as a cause of conflict. While the farmers (mean $=2.7$ ) regarded harassment of nomads by host youths as a major cause of conflict, the herdsmen (mean $=3.0$ ) also see it as a source of conflict. Farmers also agreed that stray cattle which destroy crops on the field and disregard for traditional authority also caused conflicts between farmers and Fulani Herdsmen while the herdsmen do not see both as a cause of conflict.

\subsection{Question 2: What are the social effects of the menace of Fulani herdsmen in Nigeria?}

Table 2: Social effects of the menace of Fulani herdsmen in Nigeria

\begin{tabular}{|c|l|c|c|c|}
\hline S/N & Effects & $\mathbf{N}$ & Mean & Remark \\
\hline 1. & Sexual harassment of women & 400 & 3.1 & Accepted \\
\hline 2. & Reduction in social activities & 400 & 2.3 & Rejected \\
\hline 3. & Increase in Cult related activities & 400 & 2.4 & Rejected \\
\hline 4. & High drugs intake & 400 & 2.1 & Rejected \\
\hline 5. & Acquiring of Weapons/Arms & 400 & 3.4 & Accepted \\
\hline 6. & Reduction in quality of social relationship & 400 & 2.8 & Accepted \\
\hline 7. & Reduction of social support & 400 & 2.7 & Accepted \\
\hline 8. & Loss of human life & 400 & 3.8 & Accepted \\
\hline 9. & High cases of rape & 400 & 3.3 & Accepted \\
\hline 10. & Disruption of social groups & 400 & 2.2 & Rejected \\
\hline
\end{tabular}

Mean Cut-off: 2.50

Table 2 reveals the social effects of the menace of Fulani - Herdsmen in Nigeria. The respondents agreed that the major social effect of the menace of Fulani - Herdsmen is loss of human life with 
mean of 3.8. Other social effects of Fulani - Herdsmen as agreed by the respondents are sexual harassment of human life (mean $=3.1$ ); acquiring of weapons/arms (mean $=3.4$ ); reduction in quality of social relationship (mean $=2.8$ ); reduction of social support (mean $=2.7$ ); and high cases of rape $($ mean $=3.3)$.

\subsection{Question 3: What are the economic effects of the menace of Fulani - Herdsmen in Nigeria?}

Table 3: Economic effects of the menace of Fulani - Herdsmen in Nigeria

\begin{tabular}{|c|l|c|c|c|}
\hline S/N & Effects & $\mathbf{N}$ & Mean & Remark \\
\hline 1. & Loss of produce in storage & 400 & 2.9 & Accepted \\
\hline 2. & Displacement of farmers & 400 & 2.8 & Accepted \\
\hline 3. & Reduction in output and income of farmers/ nomads & 400 & 3.4 & Accepted \\
\hline 4. & Scarcity of Agricultural products & 400 & 2.6 & Accepted \\
\hline 5. & Loss of house and properties & 400 & 2.6 & Accepted \\
\hline 6. & Low revenue generation by Government & 400 & 2.4 & Rejected \\
\hline 7. & Reduction in household resources & 400 & 2.3 & Rejected \\
\hline 8. & Infrastructural damages & 400 & 2.8 & Accepted \\
\hline 9. & Low national GDP & 400 & 2.4 & Rejected \\
\hline 10. & Diversion of national income to fight the menace & 400 & 2.2 & Rejected \\
\hline
\end{tabular}
Mean Cut-off: 2.50

Table 3 reveals the economic effects of the menace of Fulani herdsmen in Nigeria. The respondents agreed that the major economic effect of the menace of Fulani - Herdsmen is reduction in output and income of farmers/nomads with mean of 3.4. Other economic effects of Fulani - Herdsmen as agreed by the respondents are loss of produce in storage (mean $=2.9$ ); displacement of farmers (mean $=2.8$ ); scarcity of Agricultural products (mean $=2.6$ ); loss of house and properties $($ mean $=2.6)$; and infrastructural damages $($ mean $=2.8)$.

\subsection{Testing of Hypotheses}

i. There is no significant difference between farmers and Fulani perception of the causes of Fulani - Herdsmen and farmers clashes in Nigeria.

Table 4: t-test analysis for farmers and Fulani perception of the causes of Fulani - Herdsmen and farmers clashes

\begin{tabular}{|c|c|c|c|c|c|c|c|}
\hline Variations & $\mathbf{N}$ & Mean & SD & df & $\mathbf{t}_{\text {cal }}$ & $\mathbf{P}($ Sig) & Rem. \\
\hline Farmers & 250 & 26.4 & 3.80 & \multirow{2}{*}{398} & \multirow{2}{*}{1.766} & 0.109 & \multirow{2}{*}{ Not Significant } \\
\hline Fulani & 150 & 25.7 & 3.86 & & & &
\end{tabular}

$$
\text { P.>0.05 }
$$

Table 4 shows that the $t$-cal value of 1.766 is not significant because the $P$ value $(0.109)>$ 0.05 level of significance. This implies that null hypothesis is not rejected. Hence, there was no significant difference between farmers and Fulani perception of the causes of Fulani - Herdsmen and farmers clashes in Nigeria.

ii. There is no significant difference between farmers and Fulani perception of the social effects of Fulani Herdsmen and farmers clashes in Nigeria.

Table 5: t-test analysis for farmers and Fulani perception of the social effects of Fulani - Herdsmen and farmers clashes

\begin{tabular}{|c|c|c|c|c|c|c|c|}
\hline Variations & $\mathbf{N}$ & Mean & SD & df & $\mathbf{t}_{\text {cal }}$ & $\mathbf{P}($ Sig) & Rem. \\
\hline Farmers & 250 & 32.8 & 2.74 & \multirow{2}{*}{398} & \multirow{2}{*}{41.84} & $0.00^{*}$ & Significant \\
\hline Fulani & 150 & 20.3 & 2.98 & & & \\
\hline
\end{tabular}


Table 5 shows that the $t$-cal value of 41.84 is significant because the $P$ value $(0.000)<0.05$ at 0.05 level of significance. This implies that null hypothesis is rejected. Hence, there was a significant difference between farmers and Fulani perception of the social effects of Fulani - Herdsmen and farmers clashes in Nigeria. The mean score showed a significant difference which indicates that farmers' perception of the social effect of herdsmen was very high.

iii. There is no significant difference between farmers and Fulani perception of the social effects of Fulani Herdsmen and farmers clashes in Nigeria.

Table 6: t-test analysis for farmers and Fulani perception of the economic effects of Fulani Herdsmen and farmers clashes

\begin{tabular}{|c|c|c|c|c|c|c|c|}
\hline Variations & $\mathbf{N}$ & Mean & SD & df & $t_{\text {cal }}$ & $P$ (Sig) & Rem. \\
\hline Farmers & 250 & 27.44 & 2.27 & \multirow{2}{*}{398} & \multirow{2}{*}{11.31} & \multirow{2}{*}{$0.00^{*}$} & \multirow{2}{*}{ Significant } \\
\hline Fulani & 150 & 24.67 & 2.43 & & & & \\
\hline
\end{tabular}

Table 6 shows that the $t$-cal value of 11.31 is significant because the $P$ value $(0.000)<0.05$ at 0.05 level of significance. This implies that null hypothesis is rejected. Hence, there was significant difference between farmers and Fulani perception of the social effects of Fulani - Herdsmen and farmers clashes in Nigeria. The mean score showed a significant difference which indicates that farmers' perception of the economic effect of herdsmen was high.

iv. There is significant differences between farmers and Fulani perception of the economic effects of Fulani herdsmen and farmers clashes in Nigeria

\section{Discussion}

Findings from this study revealed that the major causes of Fulani - Herdsmen and farmers clashes in Nigeria are destruction of crops, harassment of nomads by host youths, disregard for traditional authority, stray cattle, sexual harassment of women by nomads and Indiscriminate bush burning and theft of cattle. This result agrees with the findings of Okereke (2012) and Bello (2013) who listed the causes of the conflict to include theft of cattle, destruction of crops, rape of women, and indiscriminate bush burning

The findings of this study also revealed that the major social effect of the menace of Fulani herdsmen are loss of human life, sexual harassment of human life, acquiring of weapons/arms, reduction in quality of social relationship, reduction of social support and high cases of rape. The major economic effect of the menace of Fulani - Herdsmen are reduction in output and income of farmers/nomads, loss of produce in storage, displacement of farmers, scarcity of agricultural products, loss of house and properties and infrastructural damages. The result agrees with the findings of Nweze (2005) and Bello (2013).

Findings on hypotheses testing revealed in hypothesis 1 that no significant difference existed between farmers and Fulani perception of the causes of Fulani - Herdsmen and farmers clashes in Nigeria. This implies that the farmers and Fulani perception of the causes of Fulani - Herdsmen and farmers clashes in Nigeria were almost the same. The finding agreed with the conclusion of Nweze (2005) who concluded that the farmers' and Fulanis' perception of the causes of Fulani Herdsmen and farmers clashes in Nigeria are similar.

Finding on hypothesis 2 and 3 revealed that significant differences existed between farmers and Fulani perception of the social effects and economic effects of Fulani - Herdsmen and farmers clashes in Nigeria. The finding agreed with the findings of Ofuoke and Isife (2009) who concluded that significant differences existed between farmers and Fulani perception of the social effects and economic effects of Fulani - Herdsmen and farmers clashes in Nigeria. 


\section{Conclusion}

This paper explores social and economic effects of the menace of Fulani's Herdsmen in Nigeria. It can be concluded that the causes of the conflict are destruction of crops, harassment of nomads by host youths, disregard for traditional authority, stray cattle, sexual harassment of women by nomads and Indiscriminate bush burning and theft of cattle. The social effect of the menace of Fulani - Herdsmen are loss of human life, sexual harassment of human life, acquiring of weapons/arms, reduction in quality of social relationship, reduction of social support and high cases of rape while the economic effect of the menace of Fulani - Herdsmen are reduction in output and income of farmers/nomads, loss of produce in storage, displacement of farmers, scarcity of agricultural products, loss of house and properties and infrastructural damages.

It was further concluded that farmers and Fulani perception of the causes of Fulani Herdsmen and farmers clashes in Nigeria are not different while farmers and Fulani perception of the social effects and economic effects of Fulani - Herdsmen and farmers clashes in Nigeria are different.

\section{Recommendation}

1. Representatives of the host communities and Fulani herdsmen should be conveyed under a public forum and involved in the decision making and permitted to take part actively in the planning procedure of restoring peace to most of the affected communities

2. Participatory planning process that involves all stakeholders (herdsmen and farmers) in the dispute resolution mechanism should be adopted.

3. Ranching method of cattle rearing should be adopted at rearing location across the country while the herdsmen should be given needed training for effective and efficient management of the ranching.

4. There is need for proper re-orientation of the essence of social interaction irrespective of the religious and ethics background

5. Government should be firm and fair in its resolution and implementation of decisions.

\section{References}

Abbas, I.M. (2009). No retreat no surrender conflict for survival between Fulani pastoralists and farmers in Northern Nigeria, Ahmadu Bello University, Zaria.

Anter, T. (2015). Who are the Fulani people and their origins? Retrieved from https://www.modernghana.com, on 17th February, 2018.

Bello, A.S. (2013). Herdsmen and Farmers Conflicts in North-Eastern Nigeria: Causes, Repercussions and Resolutions. Academic Journal of Interdisciplinary Studies.2(5): 29-139

Fabiyi, M. and Otunuga, A. (2016). Herdsmen/ farmers clashes: Nigerian government proposes ranches, herdsmen insist on grazing routes. Retrieved from www.premiumtimesnews.com/news/headlines/203225 on $21 / 12 / 2017$.

Fayinka, F. A. (2004). Food Security in Nigeria: Challenges under Democratic Dispensation.Paper Presented At $9^{\text {th }}$ ARMTI Annual Lecture, March 24, 2004.

Kasarachi, N. P. (2016). Institutionalizing peace education for sustainable development in public secondary schools in Delta State. Niger Delta Journal of Education, 8(1), 194-196.

Nweze, N,J, (2005). Minimizing farmer-herder conflicts in Fadama Areas through Local Development Plans: Implications for increased crop/livestock productivity in Nigeria. Paper presented at the $30^{\text {th }}$ Annual Conference of the Nigerian Society for Animal Production, held 20th - 24th March.

Ofuoke, A.U. and Isife, B.I. (2009). Causes, effects and resolution of farmers-nomadic cattle herders conflict in Delta state, Nigeria. International Journal of Sociology and Anthropology, 1(2), 47-54.

Okereke, D. (2012). The remote immediate cause of crimes, insecurity, terrorism and instability in Nigeria and solution. Retrieved from http://www.nairand.com/1027585/remote-immediatecauses- crimes on January 19th, 2018. 